\title{
THE ROLE OF STATE ADMINISTRATION AND LOCAL SELF-GOVERNMENT IN ENVIRONMENTAL PROTECTION
}

\author{
UDC 352:502
}

\author{
Mile Ilić1 ${ }^{1}$ Aleksandra Ilić Petković ${ }^{2}$ \\ ${ }^{1}$ University of Niš, Faculty of Education, Vranje, Serbia \\ ${ }^{2}$ University of Niš, Faculty of Occupational Safety, Niš, Serbia
}

\begin{abstract}
State administration and local self-government have numerous competences, which, according to the Constitution of the Republic of Serbia, have been elaborated through special laws. One of the specific competencies is the protection of the environment. There are many legal documents regulating this matter - from the Constitution to by-laws and acts at the level of local self-government units, so it can be said that the legal regulation in this area is extensive but not yet complete. In addition, the state administration, as a part of the state authority, plays a significant role in environmental protection policy, and local self-government authorities enable the implementation of this policy directly in immediate communication with citizens.
\end{abstract}

Key words: environmental protection, state administration, local self-government, regulations.

\section{INTRODUCTION}

Although it seems that the term "environment" is clear, it still represents a complex concept that implies air, water, soil, flora, fauna, etc. It is logical that the environment must be protected from various pollutants, and environmental issues are increasingly attracting the attention of the public, but also state authorities and local self-government bodies due to the global concern for the preservation of the environment. It is considered that, until the emergence of humankind and their influence on nature and vice versa, there was an internal harmony in the living world. Therefore, the ecological balance was disturbed by human beings and their activities. People must satisfy their needs in the environment in which they live and thus disturb the established natural balance. In fact, today there is almost no part of the planet Earth unaffected by man [2], and environmental problems are getting more and more complicated [7]. Men take from the nature what they need and return waste material, which brings the problem of environmental preservation [1-4]. Therefore, man is an entity

Received August 30, 2018 / Accepted December 20, 2018

Corresponding author: Aleksandra Ilić Petković

University of Niš, Faculty of Occupational Safety in Niš, Čarnojevića 10a, 18000 Niš, Serbia

E-mail: aleksandra.ilic@znrfak.ni.ac.rs 
that disrupts the ecological balance and, by their action or the lack of action, affects the condition of the environment. Some experts believe that the rapid increase in the number of inhabitants and the existing production processes have caused the disruption of human living conditions, such as the onset of famine, poverty, uneven economic development, and so on [15].

Due to all these and other reasons, special attention has been given to the protection and preservation of the environment for a long time, therefore, this issue is formulated through the so-called "ecological policy", which is based on clearly defined principles. On the one hand, there are ecological and social principles that imply the harmonization of economic development with ecological conditions so as not to endanger the system of the human environment. On the other hand, there are political principles, which imply the participation of various social and state entities in the environmental protection [25]. In effective ecological policy, the regulations governing this issue and the authorities that carry them out, or which are in charge of them, have a significant role. Environmental protection is increasingly becoming one of the most significant and atypical areas of social life in most European countries, which is dealt with by the national legislation of these countries, but the "civilian sector" as well. Moreover, international governmental and non-governmental organizations are also involved in the protection of the environment. In fact, today there is almost no state without special authorities in the field of environmental protection [17]. In addition to all the above mentioned subjects of environmental policy and environmental rights, the Republic of Serbia also deals with this issue, where the state administration and local self-government play an important role.

\section{STATE ADMINISTRATION BODIES IN THE FIELD OF ENVIRONMENTAL PROTECTION}

In the Republic of Serbia, environmental protection is dealt with by a large number of subjects, from state bodies to local self-government bodies. As the Constitution of Serbia prescribes that the Republic shall regulate and provide for sustainable development, system of protection and improvement of the flora and fauna, trade and production of poisonous, inflammable, explosive, radioactive and other hazardous substances [3], it is necessary for the authorities to be responsible for these tasks. State administration bodies play a significant role in this. Different laws deal with organizing different bodies for managing environmental affairs. Thus, the Law on Ministries stipulates the creation of the Ministry of Environmental Protection, as well as special organizations in this field, such as Republic Hydrometeorological Service [11]. There are also various agencies, institutes, directorates and administrations for performing the tasks in this field.

The Ministry of Environmental Protection is the most important state administration body in the field of environmental protection in Serbia. It carries out the tasks which primarily relate to the regulation of the systems of environmental protection and improvement, protection of nature, air, ozone layer, water, noise and vibrations, ionizing and non-ionizing radiation, chemical management, waste management [11]. Specific departments in this ministry deal with the mentioned issues in detail, and, among other things, there are the Department for Environmental Management, Department for Nature Protection and Climate Change, Department for Waste and Wastewater Management, etc., but this internal organization is subject to changes [19]. In addition to this, some other ministries also incorporate particular environmental issues. The Ministry of Agriculture, 
Forestry and Water Management regulates the affairs related to the analysis of the production of agricultural products, protection and use of agricultural land, etc. [11, 18]. In some segments of its work, the Ministry of Mining and Energy also deals with some issues of importance for the environment, such as making the balance of mineral raw materials, geological exploration and their exploitation, environmental protection and climate change in the field of energy, transport of gaseous and liquid carbon dioxide [11, 21]. The Ministry of Health, inter alia, deals with the health protection of citizens, food safety, hygienic drinking water supply $[11,20]$.

In addition to the ministries as state administration bodies, environmental protection is a subject of interest of state administration bodies within the ministries and special administrative organizations. Thus, the Environmental Protection Agency, which operates within the Ministry of Environmental Protection, among other things, carries out the tasks related to monitoring environmental factors through the register of pollutants, implementation of state monitoring of air and water quality, collecting environmental data, environmental protection techniques, operating a national laboratory in this area $[11,8]$. Serbian Radiation Protection and Nuclear Safety Agency is engaged in providing the conditions necessary for the effective suppression of the nefarious uses of radioactive and nuclear materials and the protection of the environment from harmful effects of ionizing radiation. It issues licenses for practice in the field of ionizing radiation and nuclear materials [24]. Within the Ministry of Agriculture, Forestry and Water Management there are several environmental management directorates. The Veterinary Directorate deals with animal health, veterinary and sanitary controls in animal trade, approval of practice of the facilities for the production of food of animal origin, animal health protection, control of food of animal origin [11, 18]. The Forest Directorate is involved in the preservation of forests, control of seeds and planting material and wildlife protection [11, 18]. There is also the Republic Water Directorate, which performs the activities related to water regime regulation, protection from water, water regime policy [11, 23].

The Institute for Nature Conservation of Serbia, which exists since 1948, has also been dealing with environmental protection. It initiates the procedures for carrying out the research on the protection of natural assets, issues work conditions in protected areas, performs expert supervision of the implementation of protective measures [9]. Republic Hydrometeorological Service acts as a separate administrative organization and represents a reference institution that carries out expert tasks and state administration tasks, which, among other things, include weather, climate and water analysis, forecast and changes, as well as making proposals for the use of the solar and wind energy potential [11, 22].

Regarding the legal status of these bodies, some of them have the status of bodies within the ministry, and some are special administrative organizations. Thus, for example, the Environmental Protection Agency has the status of a body within the Ministry of Environmental Protection, while the Veterinary Directorate, the Plant Protection Directorate, the Forest Directorate and the Republic Water Directorate operate within the Ministry of Agriculture, Forestry and Water Management. Republic Hydrometeorological Service is a separate administrative organization. The issues regarding the organization of various forms of state administration are regulated by the Law on Ministries or by special by-laws and are subject to change. 


\section{LOCAL SELF-GOVERNMENT AND ENVIRONMENTAL PROTECTION}

In addition to the Republic of Serbia, the environmental protection system is provided by the Autonomous Province of Vojvodina and local self-government units, which is defined as the achievement of an integrative ecological function [26]. However, the state authorities have the greatest competencies and, therefore, the greatest responsibility for carrying out environmental tasks. It can be considered that there is a shared competence between them and local self-government bodies, whereby the normative power of local authorities is evidently constrained.

The Law on Local Self-Government provides that the local community bodies shall take care of the environment and its protection, adopt programs of use and protection of natural values and environmental protection, that is, local action and reparation plans in accordance with the strategic document, and determine a special fee for environmental protection and improvement [10]. However, according to some data [4], local ecological action plans have been adopted by only a few dozen local self-governments, and rarely are there local selfgovernments that have adopted strategic documents in this area. This cannot be considered satisfactory, bearing in mind that there are 175 local self-government units [13].

There are several ways to achieve the ecological function of the local self-government timely and complete public information regarding the state of the environment, environmental protection through the adoption of various programs and plans, as well as monitoring and control - condition monitoring [6]. The realization of these functions is possible through various forms of organizing local self-government (e.g. a special department for the environment) or within other joint bodies. There is a possibility of engaging special advisers or an assistant mayor for environmental issues.

Inspection bodies have a special role in performing the so-called "ecological and institutional supervision", as a form of administrative control [14]. Although the activities of environmental inspection supervision are performed as entrusted tasks of the Republic, rarely are there any inspection services at the local level covering this field. They are mainly organized at district level for several municipalities.

Regarding the financing of the local self-government, one should bear in mind that there are source local self-government revenues, such as environmental protection and destruction charges, as well as some other revenues, such as fees for using natural values. Certain areas used to have special local environmental funds, but they were abolished on the grounds that they were not in compliance with the applicable laws, so there was no dedicated use of funds collected specifically and exclusively for environmental protection activities, such as "ecotaxes" for the maintenance of local greenery, etc.

Finally, there is also the so-called "ecological responsibility" for environmental pollution [6]. It is realized through certain legal and natural persons who are required to perform the tasks in this field. There is greater responsibility for non-action in this area than for wrong decisions and actions.

In the last decade, the idea of the so-called "ecological local ombudsman" ("green ombudsman") emerged [16], whose task should be more effective protection of environmental rights at the local level [5], but for now there is no data on the establishment of such an institution in Serbia. 


\section{CONCLUSION}

The issues of legal regulation of environmental protection have been lately raised due to the increasing activities on preparing Serbia's admission to the EU. Special activities are being undertaken at the opening of the chapter related to this area, which is considered one of the most complicated, but is intensively worked on. In this regard, environmental protection in Serbia is dealt with by numerous subjects, from state bodies to local selfgovernment bodies.

State administration, although it does not represent a type of state authority, but a function of executive power [12], plays a significant role in the environmental protection system. This is proved by the fact that there is a special ministry exclusively dealing with environmental issues - the Ministry of Environmental Protection. Although it only exists since 2017 [11], its intense activity on the improvement of legal regulations in this area is being noted, which is confirmed by the Draft Law on Climate Change. A public discussion was held regarding this matter and its adoption is expected in the near future. In addition to this ministry, other ministries indirectly deal with the environment within their competencies, such as the Ministry of Health, the Ministry of Energy, Mining and Water Management, the Ministry of Agriculture, etc.

In addition to the Ministry of Environmental Protection, as the most important state administration body, administrative bodies within the ministries are also involved in environmental affairs, focusing on certain segments of the environment. Thus, there is the Environmental Protection Agency within the Ministry of Environmental Protection, the Forest Directorate and Veterinary Directorate within the Ministry of Agriculture, Forestry and Water Management, etc. Their importance for the environment is reflected in the fact that they deal with state administration affairs in individual segments of the environment, but thoroughly implement the policies in a given area. Finally, special administrative organizations that enjoy the status of autonomous institutions also cover environmental affairs, such as Republic Hydrometeorological Service.

When it comes to the local self-government, its organs have many options for acting in the field of environmental protection, starting from ecological inspection, environmental ombudsman, and ecological taxes. Local self-government units decide to what extent they will use these opportunities, while the state creates preconditions for this.

Based on all of the above, it can be concluded that in Serbia, both state administration and local self-government are involved in environmental issues. Legal assumptions for their functioning do exist and this is recognized in the state administration since there is a ministry whose exclusive competence is the environment, but there are also many other forms of state administration activities. The activity in environmental protection is more limited at the local level, but it can be increased. Therefore, it is the obligation of the scientists and experts in this area to promote the ecological awareness of citizens at this level as well.

\section{REFERENCES}

1. Anđelković, В. (2010). Основи система заштите (Fundamentals of Occupational Safety). Niš: Fakultet zaštite na radu.

2. Biermann, F. (2010). Earth System Governance and the Social Sciences, in Environmental Sociology European Perspectives and Interdisciplinary Challenges, pp. 59-78.

3. Constitution of the Republic of Serbia, Official Gazette of the Republic of Serbia, No. 98/2006. 
4. Cvijović, M. (2013). Reforma javne uprave i lokalna samouprava u Srbiji (Public Administration Reform and Local Self-Government in Serbia), doktorska disertacija. Beograd: Fakutet političkih nauka.

5. Dimitrijević, P. (2006). Lokalni ombudsman (Local Ombudsman). Pravni život, 55(10): 317-328.

6. Dimitrijević, P., Vučetić, D., Vučković, J. (2016). Sistem lokalne samouprave: norma i proces (Local Self-Government System: Norm and Process). Niš: Sven.

7. Dunlap, R. (2010). The Maturation and Diversification of Environmental Sociology: From Constructivism and Realism to Agnosticism and Pragmatism, in The International Handbook of Environmental Sociology, 15-32.

8. Environmental Protection Agency: http://www.sepa.gov.rs (accessed 22.7.2018.)

9. Institute for Nature Conservation of Serbia: http://www.zzps.rs/novo/index.php?jezik=sr\&strana=naslovna (accessed 29.7.2018.)

10. Law on Local Self-government, Official Gazette of the Republic of Serbia, No.129/2007, 83/2014, 101/2016, 47/2018.

11. Law on Ministries, Official Gazette of the Republic of Serbia, No. 44/2014, 14/2015, 54/2015, 96/2015, $62 / 2017$.

12. Law on State Administration, Official Gazette of The Republic of Serbia, No. 79/2005, 101/2007, 95/2010, 99/2014, 47/2018, 30/2018.

13. Law on Territorial Organization of the Republic of Serbia, Official Gazette of the Republic of Serbia, No. 129/2007, 18/2016, 47/2018.

14. Lilić, S.(2007). Ekološka inspekcija u zakonodavstvu Srbije i EU (Ecological Inspection in the Legislation of Serbia and the EU), u Pedeset godina Evropske unije - Zbornik radova, str. 277-287.

15. Lilić, S. (2011). Instrumenti ekološke pravde (Instruments of Ecological Justice), u Ekologija i pravo Zbornik radova, str. 3-22.

16. Lilić, S., Drenovak Ivanović, M. (2014). Ekološko pravo (Ecological Law). Beograd: Pravni fakultet.

17. Lončar, Z. (2012). Organizacija uprave u oblasti zaštite životne sredine (Organization of the Administration in the Field of Environmental Protection). Zbornik radova Pravnog fakulteta u Nišu, 59:105-121.

18. Ministry of Agriculture, Forestry and Water Management: http://www.minpolj.gov.rs (accessed 25.7.2018.)

19. Ministry of Environmental Protection: http://www.ekologija.gov.rs (accessed 29.7.2018.)

20. Ministry of Health: http://www.zdravlje.gov.rs (accessed 26.7.2018.)

21. Ministry of Mining and Energy: http://www.mre.gov.rs (accessed 29.7.2018.)

22. Republic Hydrometeorological Service of Serbia: http://www.hidmet.gov.rs (accessed 20.7.2018.)

23. Republic Water Directorate: http://www.rdvode.gov.rs (accessed 19.7.2018.)

24. Serbian Radiation Protection and Nuclear Safety Agency: http://www.srbatom.gov.rs/srbatom/ (accessed 29.7.2018.)

25. Vasić, S. (2004). Uloga države u neutralisanju ekoloških eksternih efekata (The Role of the State in Neutralizing Ecological External Effects). Niš: Ekonomski fakultet.

26. Vučković, J. (2011). Uloga i značaj lokalne samouprave u zaštiti životne sredine (The Role and Significance of Local Self-Government in Environmental Protection), u Ekologija i pravo - Zbornik radova, str. 477-489.Hedrih (Stevanović) K., (2001), Vector Method of the Heavy Rotor Kinetic Parameter Analysis and Nonlinear Dynamics, University of Niš 2001, Monograph, p. 252. YU ISBN 86-7181-046-1 UDC 531.38:514.742.4

\section{ULOGA DRŽAVNE UPRAVE I LOKALNE SAMOUPRAVE U ZAŠTITI ŽIVOTNE SREDINE}

Postoje mnogobrojne nadležnosti državne uprave i lokalne samouprave koje su, na osnovu Ustava Republike Srbije, razrađene kroz posebne zakone. Jedna od specifičnih nadležnosti je zaštita životne sredine. Brojni propisi uređuju ovu materiju - od Ustava do podzakonskih akata $i$ akata na nivou jedinica lokalne samouprave, pa se može reći da je pravna regulativa u ovoj oblasti obimna, ali još uvek ne i potpuna. I pored toga, državna uprava, kao funkcija državne vlasti, ostvaruje značajnu ulogu u politici zaštite životne sredine, a organi lokalne samouprave omogućavaju realizaciju te politike na neposredan način u direktnoj komunikciji sa građanima.

Ključne reči: zaštita životne sredine, državna uprava, lokalna samouprava, propisi, politika. 